\title{
The Ethics of Kin State Activism: A Cosmopolitan Defense
}

\author{
George Vasilev
}

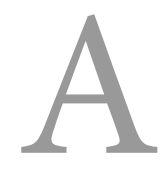

notable feature of nationalism's contemporary resurgence is the increasing eagerness that governments have shown to support and shape the political causes of populations living abroad whom they conceive of as ethnic kindred. Governments engaged in such "kin state activism" assume a natural entitlement to speak for and assert authority over minorities and diasporas in other states, invoking a belief in common territorial, cultural, and even biological origins as a moral basis for that entitlement. A striking example of the trend is the Russian government's declaration that it will defend the interests of ethnic Russians wherever they may be and regardless of their citizenship. ${ }^{1}$ The government has made good on this intention since 2014 through the invasion of Crimea and through support for pro-Russia secessionist fighters in eastern Ukraine. Russian officials have also made thinly veiled threats to apply the doctrine in Estonia, Lithuania, and Latvia, where large Russian-speaking minorities reside and maintain strained relations with authorities. ${ }^{2}$

Kin state activism has also become increasingly apparent in other contexts, even though it has not involved the military coercion and flagrant disregard for international law characterizing Russia's interventions. Examples that have made headlines recently include Hungarian Prime Minister Viktor Orbán and his Fidesz (Federation of Young Democrats) party's cross-border political collaborations with Romania's Hungarians, ${ }^{3}$ Turkish President Recep Tayyip Erdoğan's appeal to Greek Prime Minister Alexis Tsipras to take action against the discrimination of Greece's predominantly ethnic Turkish Muslims, ${ }^{4}$ and Croatian President Kolinda Grabar-Kitarović's lobbying for electoral reform in Bosnia so that ethnic Croats there can gain increased representation. ${ }^{5}$ These and other examples typify a trend in which governments are more stridently assuming a right to protect,

Ethics \& International Affairs, 33, no. 4 (2019), pp. 395-410.

(C) 2019 Carnegie Council for Ethics in International Affairs

doi:10.1017/So892679419000388 
counsel, represent, politically organize, indoctrinate, naturalize, financially support, advocate for, and even govern populations beyond state jurisdictions on the basis of an ethnic conception of shared identity.

\section{Ethical Dilemmas}

The profusion of kin state activism and the controversy that surrounds it raises ethical dilemmas on how this political practice should be evaluated and handled. On the one hand, kin state activism is straightforwardly objectionable. It is motivated by an exclusionary ideology that ranks human beings along an ethnic hierarchy of worth. If this is an unacceptable basis for political community at the domestic level, it should also be disavowed at the international level, given that it consists of the same arbitrary use of state power to advance the opportunities of one group of individuals ahead of another.

Moreover, kin state activism challenges the notion that states should have final authority over their own territories, potentially with disastrous consequences for international cooperation. The intensification of external influence over domestic policymaking raises the concern that the force of sovereignty as a nonintervention norm will be fatally eroded. Under such conditions, an important constraint on interstate behavior is diminished. This can create license for military interventions beyond jurisdictions in order to protect one's "own people," as witnessed in the former Yugoslavia during the 1990s and Nazi Germany during the Second World War.

On the other hand, any outright repudiation of kin state activism is complicated by the observation that minorities are frequently subjected to genuine forms of oppression against which the international community has a responsibility to act. At the extreme end, such oppression includes ethnic cleansing, crimes against humanity, and genocide. All member states of the United Nations have made a commitment to prevent such atrocities (by military force, if necessary) under the Responsibility to Protect (RtoP) principle. ${ }^{6}$ However, there are less extreme but more ubiquitous forms of oppression that also violate international law and can be legitimately opposed through externally imposed pressure not involving the use of military force. Such oppression includes prohibitions on the expression of minority identities and restrictions on the freedom of minorities to reproduce their cultures-injustices that are perpetuated under nation-building policies designed to establish the dominance of a single ethnic group over a territory. 
Assimilatory and exclusionary practices of this kind are an infringement of minority rights norms embedded in the treaties of intergovernmental bodies, such as those of the United Nations and the Council of Europe. These statements of principles set regional and global standards for governing ethnic diversity and are intended to protect vulnerable minorities from the predations of statecontrolling ethnic groups. States that fall foul of these standards are pressured by international organizations, international courts, nongovernmental organizations, and concerned national governments to reform domestic law and institutions so that they conform to global benchmarks on the treatment of minorities. ${ }^{7}$

Kin state activism can be a constructive part of the pursuit of individual and collective rights by these cross-border monitoring and compliance regimes, despite being underpinned by a narrow conception of solidarity based on ethnicity. The cultural affinities that draw a state toward a persecuted kindred population beyond its own confines can serve as a dependable source of support whenever the rest of the world is turning a blind eye to that population's plight. Support of this kind is especially important given that international organizations do not always act in the best interest of minorities, despite recognizing their global responsibility to promote minority rights. International organizations are beholden to the agendas of their member states, which often bring national interest rationales into decision-making that can be unsympathetic, even hostile, toward minority concerns. Under such circumstances, the advocacy of kin states is justifiable because it addresses the failure of the wider international community to consistently enforce minority rights and to meaningfully take a stand against states that mistreat their citizens on the basis of ethnicity.

Indeed, if one is persuaded by Michael Walzer's maxim "Whoever can, should," 8 then kin states are one among various permissible and efficacious vehicles for alleviating the abuse of minorities and advancing just relations between ethnic groups in a world where security and welfare are enjoyed unevenly. As state actors, kin states bring to reform campaigns capabilities relevant for making the biggest difference. They possess the bureaucratic machinery, human capital, and economic resources to end the political marginalization and cultural subordination of minorities in other states through diplomatic, economic, political, and social channels. This sets kin states apart from human rights NGOs, which are dependable allies of oppressed minorities but, as nonstate actors, must rely on a more limited repertoire of influence, largely consisting of publicity campaigns and naming and shaming strategies. On their own, these social and discursive 
pressures are not always effective in compelling repressive governments to enact domestic policy that complies with minority rights norms, despite being vital in raising global awareness about the infringement of those rights and generating public sympathy toward groups seeking to overcome discrimination, marginalization, and state violence.

Currently, global standards for judging when kin state activism is and is not acceptable are underarticulated or avoided entirely, as the objectionable instances of kin state behavior tend to overshadow the legally and morally consistent ones. The most comprehensive standards exist at the European level, codified in the Venice Commission Report, issued in 2001, and the Bolzano/Bozen Recommendations on National Minorities in Inter-State Relations \& Explanatory Note, issued in $2008 .^{9}$ However, these quasi-legal documents prohibit kin states from taking direct action against home states to end minority repression. The code of conduct embodied in the documents restricts extraterritorial interactions merely to the allocation of cultural and educational resources, such as the financing of schools and media for minorities. ${ }^{10}$ Importantly, the legitimacy of such cross-border initiatives is premised on the consent of home states and the preservation of friendly state relations. ${ }^{11}$ Under these constraints, states are denied the opportunity to assume a leadership role in the enforcement of human rights whenever kindred groups are on the receiving end of violations. At the same time, the protection of people from arbitrary coercion is subordinated to conflict management and state sovereignty rationales. ${ }^{12}$

In contrast to these approaches, I believe the analysis of world affairs and promotion of global justice would benefit from an ethic of transnational conduct that permits kin states to keep others answerable for the mistreatment of minorities. Such an ethic should be based on a cosmopolitan logic, encompassing a set of rules and guidelines that advances a general human solidarity premised on supportive relations across state boundaries and that takes seriously the human rights obligations owed to people at a distance. It would share certain characteristics with the RtoP principle. Foremost among them would be an emphasis on the interests of people living in circumstances of vulnerability, the prevention or eradication of harm-doing, the entitlement of victimized populations to receive external assistance without their government's consent, and the initiation of action in a timely and decisive manner.

However, the ethic would diverge from RtoP in crucial ways as well, filling prescriptive gaps on how injustices specific to ethnic groups are approached under 
that principle. First, it would have built into it a lower threshold for action. It would be designed to rectify all types of human rights abuses, not simply those consisting in atrocity crimes. Second, the ethic would offer guidance on the use of nonmilitary measures. While peaceful means of transnational accountability do figure into RtoP guidelines, ${ }^{13}$ the principle's primary focus is on armed intervention and its regulation. Finally, the ethic would not treat the buy-in of the world's major powers as an overriding standard of validity. It would thus stand in contrast to the ironclad requirement under RtoP that states gain prior approval from the United Nations Security Council before undertaking a military intervention. Such a consensus rule is an excessively cautious precondition to impose on interventions that are peaceful and dissociated from lethal force. Avoiding it would unburden campaigns of minority protection from the obstruction and politicking of veto-wielding members in the Security Council. This is important since some members, notably China and France, have notoriously poor track records on minority-related issues and are therefore inclined to avoid cooperation and foster dysfunction. ${ }^{14}$

The appeal of enumerating and adopting such a vision of transnational accountability over treating it as taboo is that it enables us to recognize and combat the dangers posed by certain forms of kin state activism without forgoing the opportunities presented by other forms. It also invites us to place ourselves in the shoes of vulnerable substate groups-as opposed to privileging states-when judging what is the right thing to do in response to competing claims over rights and interests. Indeed, there is a clear moral difference between peacefully and constructively taking a stand against the repression and hatred of kindred populations abroad and unscrupulously cultivating nationalistic loyalties with kindred populations abroad that alienate them from fellow citizens and destabilize their home states. Examples of the former might include the diplomatic pressure asserted by Arab states to end Israel's deprivation of Palestinians, Israel's expression of concern toward the rising tides of antisemitism in Eastern Europe, and Turkey's call for the United Nations to end the mass internment of Uighurs in China. Examples of the latter might include the Hungarian government's effort to court Romania's Hungarian minority as an extraterritorial voting bloc, Croatia's meddling in Bosnia's electoral politics to strengthen the hand of ethnic Croat political parties, and Albania's newfound irredentist rhetoric entertaining the prospect of Albanian political unification in the Balkans. It would be a mistake 
to reject the legitimacy of the former set of actions simply because one is repelled by the latter set.

A cosmopolitan kin state ethic permits us to avoid such a blunt reaction. It makes distinctions between good and bad forms of kin state behavior and therefore offers a rationale for action attuned to the ethical complexities arising from relationships among a foreign lobby state, an ethnic group receiving its patronage, and a home state where that ethnic group resides. I propose the criteria below as suited to fulfilling these evaluative and prescriptive functions. As will become apparent, these criteria furnish an ethic that is prudent. While its intention is to spread tolerance, inclusion, and the fair governance of ethnic minorities globally, the ethic carries a set of prohibitions against extraterritorial nation-building and military operations by states exploiting supposed kindred populations to project power abroad. The ethic therefore serves as a critical vantage point for condemning, and not encouraging, the predatory and destabilizing forms of kin state behavior currently making international headlines.

\section{The Four Criteria}

\section{Activism Is in Reaction to Harm}

As a minimum condition of legitimacy, kin state activism must be in reaction to the perpetration of harm involving physical and/or mental injury. Such groupspecific harm can take various forms. ${ }^{15}$ The most extreme consist of violations of the body through murder, assault, rape, torture, and enslavement-acts of savagery that incite global outrage and are a trigger for humanitarian interventions with military force.

Other harms that stop short of killing and maiming, but can nevertheless be rightful grounds for opposition by external actors and kin states specifically, include "domination," whereby a group is prevented from expressing its culture and pursuing interests vital to its well-being under policies of forced assimilation and political exclusion; "misrecognition," whereby a group is publicly degraded and maligned, leading to systematic discrimination and the impairment of its positive self-understanding; "exploitation," whereby a group is confined to menial, dirty, and dangerous professions or tasks from which others unfairly profit; and "deprivation," whereby a group is marked by poverty, unemployment, low-quality housing, inadequate health provision, and high infant mortality rates, along with diminished educational prospects, social mobility, and life expectancy. ${ }^{16}$ 
Though devoid of the grotesque violence and extreme cruelty of humanitarian emergencies, these harms burden individuals with physical and mental suffering in their everyday interactions and can greatly shorten their lives. ${ }^{17}$ Moreover, their perpetuation is a breach of the fundamental interest people have to be free from suffering. ${ }^{18}$ It is these realities that provide a cosmopolitan source of legitimacy for shaping the domestic affairs of another state. Insofar as all people deserve equal moral consideration and have an interest in avoiding harm, cross-border initiatives to alleviate the oppression of ethnic groups and to ensure their security and welfare can claim validity from a universalist perspective, even if the parochial affinities of kin states happen to be behind those initiatives. Action carried out with those purposes fulfills the global responsibility to provide assistance to people in need. It also realizes the entitlement of all people to be protected from bodily and mental suffering.

At the same time, such a duty to assist those in jeopardy does not entail an "anything goes" ethic. On the contrary, a kin state ethic conceived through a harm criterion significantly limits the scope of permissible activism. What matters normatively is the alleviation of insecurity and misery brought on by domination, misrecognition, exploitation, or deprivation. Activism that fails to serve one of those moral purposes cannot count as an acceptable intrusion into the domestic affairs of states to shape how they govern diversity over their territories.

These qualifications should allay the well-founded fear that a kin state ethic might too easily avail itself as an instrument of abuse and misuse in international relations. By confining the parameters of rightful action to instances of genuine harm, the ethic cannot be plausibly enlisted to advance the fortunes of one externally located population to the disadvantage of others through nonresident citizenship, patronage arrangements, or other forms of preferential treatment.

Present-day examples embodying this type of unprincipled behavior include Serbia's and Croatia's patronage of kindred groups in Bosnia ${ }^{19}$ and that of Albania in Kosovo and Macedonia. ${ }^{20}$ These cross-border relationships consist in offers of nonresident citizenship, the coordination of political parties and advocacy groups advancing ethnic interests, proposals for political unification (in the case of Albania), and support for secessionist leaders (in the case of Serbia). Yet there is no systematic repression to warrant such external lobbying and intrusions in the domestic affairs of another state. On the contrary, the kindred populations concerned are dominant members in their respective societies. 
These unwarranted instances of kin state activism can be contrasted to those arising under circumstances of targeted coercion causing psychological and physical harm. For example, in the mid-1990s, Hungary pressed Yugoslav leaders to end their campaign of "quiet ethnic cleansing" against the Hungarian minority, who were being subjected to systematic intimidation, beatings, bombings, death threats, rape threats, and forced evictions from their homes. ${ }^{21}$ The same type of protest action involving formal complaints and official denouncements was taken by Albania in the 1990s and early 2000s, when Albanians in Kosovo were subjugated under a brutal apartheid style system and Albanians in Macedonia were marginalized politically and discriminated against societally. ${ }^{22}$ Kin state mobilization in each of these cases was desirable and necessary, as it confronted serious coercion against people who were powerless to protect themselves and was aimed at affecting changes that deepen compliance with human rights.

\section{Influence Is Proportionate to Harm}

The activism of kin states must also follow a principle of proportionality: The remedial means deployed should be proportionate to the harmful practices they seek to eradicate. Specifically, the measures taken should neither exceed the amount necessary for inducing a state to contemplate ceasing its perpetuation of harm nor shift human suffering to new populations and locations.

Russia's invasion of Ukraine and its support of Ukrainian armed insurgents is an obvious example of such disproportionate force. In the years preceding the intervention, several laws were passed to make Ukrainian the country's sole official language, disadvantaging monolingual members of its large Russian-speaking population. ${ }^{23}$ This was a retrograde development from the perspective of ethnocultural justice. However, it did not constitute valid grounds for Russia's military operations and seizure of Ukrainian territory. Such a violent reaction goes beyond any globally shared notion of proportionate force. Nor does Ukraine's linguistic homogenization of the public sphere amount to the "persecution" of ethnic Russians, as Vladimir Putin declared. ${ }^{24}$ After all, Ukraine's Russian-speaking minority has remained free to organize itself collectively and promote causes tied to its heritage, despite the injustices of the new language laws. ${ }^{25}$

In contrast to such unnecessary and counterproductive uses of force, there are a variety of alternatives that can strike the right balance between means and ends. At the lower end of the intensity scale, those alternatives involve acts of persuasion, whereby the kin state urges the home state to consider the correctness of observing 
human rights and their universally binding nature. The success of such moral and educative communication becomes more probable whenever it is coupled with actions that allay irredentist or secessionist fears. This could consist in the kin state working jointly with the home state and international organizations to disempower insurgents, demilitarize border regions, and establish the rule of law there. It could also consist in the kin state denouncing secessionism and recognizing as legitimate only those minority representatives who envision a future under existing territorial boundaries.

For example, Ireland's decision to drop its irredentist claim over Northern Ireland and persuade paramilitaries to decommission their weapons was instrumental in nurturing openness among Protestants to giving up their political hegemony and sharing power with Catholics under the Good Friday Agreement, signed in $1998 .{ }^{26}$ Likewise, it was only after Austria relinquished its irredentist claims over South Tyrol through the Gruber-De Gasperi Agreement, passed in 1946, that the Italian government acknowledged the distinct character of the region's German speakers and later accepted their demands for territorial autonomy after decades of forced Italianization. ${ }^{27}$

Trust-building overtures of this nature are conducive to the desecuritization of interstate and minority-state relations, creating conditions favorable for the reinterpretation of minority rights as an uncontroversial element of coexistence and an aspect of what it means to be a responsible member of international society. At the same time, they diminish the likelihood of minority rights being interpreted as a threat to statehood and national survival. ${ }^{28}$

Whenever the force of reason and geopolitical assurances are ineffective, kin state pressure can be escalated to include adversarial types of engagement. The aim of such encounters is to disrupt and inconvenience, rather than establish cooperation and find common ground. This pressure can involve social techniques of enforcement, such as drawing worldwide attention to harmful practices with a view to shaming and damaging the reputation of the perpetrator state. It can also involve the extension and retraction of material incentives, such as economic, military, and diplomatic resources that are important for the prosperity of the perpetrator state and legitimacy of its leaders. Furthermore, it can involve indirect routes of pressure, whereby the kin state rallies international organizations and middle and great powers to condemn, politically shun, and economically sanction the home state over its continued repression of a minority. 
International leverage of this kind pushes targeted actors to abide by minority rights norms through tactical concessions - that is, through a calculus of avoiding costs and retaining benefits. ${ }^{29}$ No doubt, such a strategy raises tensions when a targeted state balks at the directives and ultimatums handed down, and reacts angrily at being criticized and having its privileges taken away. Yet, this does not constitute a breakdown of international order. On the contrary, it is in accord with the rules, agreements, and expectations sustaining international peace, security, and cooperation. After all, such nonviolent action is the primary means through which antisocial states are confronted and rule-compliant behavior is enforced across the enormous range of issue areas animating world affairs..$^{30}$ For these reasons, a kin state's use of social and material sanctions to deter another state's repression of minorities is consistent with shared understandings of proportionality. It should be regarded as justifiable, even salutary, whenever reasoned exchanges and appeals to the universal validity of human rights repeatedly fail to achieve the desired result.

\section{Activism Seeks Compliance with Values, Not Institutional Designs}

The kin state should also be seeking compliance with values enshrined in international harm conventions; it should not be dictating which preconceived institutional designs must be adopted to realize its agenda. The precise nature of designs should be determined inside the home state through a negotiation between the kindred group and other members of society who search for a principled compromise that takes into account each other's concerns and priorities. In these terms, the kin state's role is to facilitate movement toward harm eradication and to ensure a perpetrator state is acting in good faith when it commits to taking this path. Beyond this initiative and oversight function, the kin state's role ends. Concrete questions on how values are best translated into policies, laws, and practices are a matter for domestic actors to address through a democratic exchange of reasons that establish the most justifiable solution.

Value-oriented activism of this kind characterized Albania's response to the democratic marginalization, brutalization by police, and cultural degradation of Macedonia's Albanians during the 1990s and early 2000s. At the time, Albanian state officials brought these problems to the attention of their Macedonian counterparts and urged them to respect the human rights of Albanians, but did not specify what kind of measures needed to be adopted to satisfy that plea. $^{31}$ When tensions escalated into an armed conflict involving guerrilla fighters demanding equality for the Albanian minority, Albania condemned the 
insurgency and instructed Albanians to redress their grievances within Macedonia's political institutions and in accordance with values embedded in Europe's regional organizations. ${ }^{32}$

Albania's use of value-based rhetoric can be contrasted with Croatia lobbying for ethnically defined electoral constituencies and a Croat-controlled federal unit in Bosnia. ${ }^{33}$ Such cross-border projections of power are a greater intrusion in the domestic policy-making process, as they amount to pressure to do something specific; namely, to implement an explicit set of institutions that undermines Bosnia's precarious foundations of coexistence established in the Dayton Accords

The purpose of confining foreign activism to the abstract level of values and prohibiting it at the ground level of institutions is to avoid entrenching a dubious cosmopolitan paternalism that wrests control over decisions on coexistence from domestic actors and places it in the hands of outsiders. A reform campaign that is tied to values - in this instance, ones pertaining to equal moral consideration for all people-is agnostic to the numerous arrangements of coexistence that can enable their realization. An initiative of this kind does not push a specific multicultural architecture as definite and binding on all. Instead, it offers scope for domestic actors - those with the greatest stake in reforms-to determine for themselves which practical solutions are best suited to resolving the problem of grouptargeted harm in their society.

These solutions can take an integrationist character, such as legal change to ensure equality before the law; a differentiated character, such as affirmative action programs to establish inclusion in public institutions; or a separatist character, such as power sharing and territorial autonomy to enable self-governance. Ultimately, the choice of which form to take should be exercised inside states, thereby preserving the self-determination of domestic actors and leaving them at liberty to tailor arrangements of coexistence to the specificities of their context.

This approach to institutionalization is ad hoc and scaled down. But it is not relativist. It still retains a place for external evaluation according to how adequately the resultant arrangements protect a vulnerable group and the extent to which the arrangements were chosen without the group's coercion. The prioritization of human rights values in the approach offers a universal yardstick for carrying out such a context-transcending appraisal and taking remedial action where required.

The ethical import of this formulation is that a kin state can rightfully intervene in and bring principled pressure to bear on negotiations over institutional choices 
whenever the home state behaves as a spoiler or forces the kindred group to consent to a proposal that fails to bring it security and well-being. This external watchdog function ensures that the localization of international values does not lose sight of its original purpose-the elimination of harm-doing-especially under the power disparities that define the kindred group's interactions with the home state, and thus leave the reform process exposed to the latter's capture and distortion.

\section{Reform Is Pursued in a Transnational Network of Human Rights Actors}

The kin state should also pursue reform as part of a larger transnational network dedicated to the spread of human rights. Such networked advocacy encompasses an array of actors-state and nonstate, domestic and international.

While the composition of a kin state's advocacy network can be diverse and broad, the involvement of civil society actors and supranational institutions is crucial for enhancing the network's ethical legitimacy. Human rights NGOs such as Human Rights Watch and supranational institutions such as the European Court of Human Rights are not bound by the justifications of any individual state, the conventions of diplomatic niceties, or the fear of upsetting allied or rival states. ${ }^{34}$ Consequently, they can often serve as a reliable source of facts and opinions on the treatment of minorities and, by extension, as a reliable moral check on the conduct of the kin states that defer to their information and judgments.

The ethical contribution these nonstate actors make to an advocacy network is evident when one considers the complementary division of labor each is equipped to perform. Human rights NGOs are adapted to establish the empirical validity of allegations that a kindred group is being harmed. Their close domestic contacts and independence from nation-states enables them to carry out fact-finding missions that are nonpartisan and receptive to the experience of individuals subjected to state power. Similarly, supranational courts are adapted to establish the legal validity of those allegations. Their ideological and institutional distance from states enables them to withstand the intrusion of instrumental imperatives and stay faithful to harm principles embedded in international conventions when weighing up evidence, making rulings, and issuing advisory opinions. Considered in this light, kin state activism that is not aligned with human rights NGOs or supranational institutions should be treated as ethically dubious. Without the corroboration of these external bodies, it is much more difficult to 
determine whether allegations of kindred group repression have been accurately reported.

An example of kin state activism embedded in a transnational network promoting human rights is the efforts by Turkey and Macedonia at easing Greece's uncompromising assimilatory policies. Greece denies the existence of Turkish and Macedonian minorities on its territory and has kept them societally invisible by prohibiting the public use of their languages, banning associations promoting their cultures, and imposing harsh penalties on local activists campaigning for ethnic equality. Turkey and Macedonia have underscored the injustices of this assimilatory program and urged Greece to adopt a more tolerant form of nationhood, a stance that aligns with the opinions of such domestic and global actors as the European Court of Human Rights, Greek Helsinki Monitor, and the UN Human Rights Council. ${ }^{35}$

Contrast this with Russia's invasion of Georgia in 2008. At the time, Russia claimed to be rescuing kindred populations from a "humanitarian catastrophe." ${ }^{36}$ This claim, however, was rejected as groundless by the wider international community. The prevailing view was that Russia was using allegations of minority abuse and RtoP-like language as a camouflage for reasserting geopolitical dominance through military force after Georgia attempted to break free from Russia's sphere of influence and align itself with NATO and the EU. ${ }^{37}$

\section{Conclusion}

There is cosmopolitan value in kin states. At their best, they can be dependable players for confronting oppressive relations, promoting human rights, and enhancing international peace and cooperation. Given this, we need to expand our ethical horizons to understand them as an acceptable component of collective endeavors aimed at realizing equal well-being for all people. The four criteria I have put forward are a starting point for such a reappraisal. They help us distinguish kin state conduct that fulfills the requirements of cosmopolitan justice from kin state conduct that is founded on chauvinism, aggression, intolerance, and irredentism.

Each of the criteria should be understood as a compulsory requirement of legitimacy, rather than open to exceptions, as kin state action that fails to observe all of them is seriously deficient from a cosmopolitan standpoint. Indeed, without the presence of oppression or other harm, kin state support embodies the moral 
arbitrariness of ethnonationalism. Likewise, without the proportionate use of force, kin state intervention descends into recklessness that inflicts new harms in the name of preventing existing ones. Without the open-endedness of a valuebased rhetoric, kin state demands for change become excessively paternalistic, inhibiting the other political community from governing itself on its own terms. And finally, without the check of a human rights-based advocacy network, claims of persecution cannot be reliably authenticated.

Soft law instruments like the Bolzano/Bozen Recommendations that currently regulate kin state behavior through a conflict management rationale would benefit from incorporating the ideas of this justice-oriented framework. Not only is there intrinsic worth to a life free from oppression but also instrumental worth, as such a life is conducive to peaceful social relations. Indeed, it is the experience of suffering at another's hands that frequently stimulates deep-seated resentment, a lack of identification with the political order, and a desire to secede and create a society that better guarantees the safety and dignity of one's group. ${ }^{38}$ The conflict management goals of international law would therefore be served rather than threatened by prescriptions permitting kin states to keep other states answerable for the mistreatment of their people.

\section{NOTES}

${ }^{1}$ Steven Piver, "Mr. Putin: Turning Neighbor into Adversary (Op-Ed)," Moscow Times, October 31, 2017, www.themoscowtimes.com/2017/10/31/mr-putin-turning-neighbor-into-adversary-op-ed-a59432.

${ }^{2}$ Max Fisher, "Russia Is Starting to Use the Same Line on Baltic Countries That It Used to Invade Ukraine," Vox, October 1, 2014, www.vox.com/2014/10/1/6880329/russia-baltic-threats-ukraine-estonia.

3 Simone Benazzo, Martina Napolitano, and Marco Carlone, "Hungary's Orban Woos Romania's Restive Hungarians," Balkan Insight, November 27, 2017, balkaninsight.com/2017/11/27/hungary-s-orbanwoos-romania-s-restive-hungarians-11-24-2017/.

${ }^{4}$ Helena Smith, "Confrontational Erdoğan Stuns Greek Hosts on Athens Visit," Guardian, December 7 , 2017, www.theguardian.com/world/2017/dec/07/turkish-president-erdogan-to-make-landmark-visitto-greece.

5 Sven Milekic, “Croatian President Seeks Erdogan's Help over Bosnia,” Balkan Insight, January 9, 2018, balkaninsight.com/2018/01/09/croatian-president-asks-for-erdogan-s-help-over-bosnia-01-09-2018/.

${ }^{6}$ Alex J. Bellamy, The Responsibility to Protect: A Defense (Oxford: Oxford University Press, 2014).

7 Will Kymlicka, Multicultural Odysseys: Navigating the New International Politics of Diversity (Oxford: Oxford University Press, 2007).

8 Michael Walzer, "On Humanitarianism: Is Helping Others Charity, or Duty, or Both?," Foreign Affairs 90, no. 4 (July/August 2011), p. 79.

9 Francesco Palermo, "National Minorities in Inter-State Relations: Filling the Legal Vacuum?," in Francesco Palermo and Natalie Sabanadze, eds., National Minorities in Inter-State Relations (Leiden, Netherlands: Brill, 2011), pp. 5-6, 12; and Zsuzsa Csergo" and James M. Goldgeier, "Kin-State Activism in Hungary, Romania, and Russia: The Politics of Ethnic Demography," in Tristan James Mabry, John McGarry, Margaret Moore, and Brendan O’Leary, eds., Divided Nations and European Integration (Philadelphia: University of Pennsylvania Press, 2013), p. 107.

10 Palermo, "National Minorities in Inter-State Relations," p. 15.

${ }^{11}$ Ramesh Thakur, "The Responsibility to Protect: A Forward-Looking Agenda," in Walter Kemp, Vesselin Popovski, and Ramesh Thakur, eds., Blood and Borders: The Responsibility to Protect and the Problem of the Kin-State (Tokyo: United Nations University Press, 2011), p. 57. 
12 Gábor Kardos, "Role for the Kin-States?," in Osamu Ieda and Balázs Majtényi, eds., Beyond Sovereignty: From Status Law to Transnational Citizenship? (Sapporo, Japan: Slavic Research Center, Hokkaido University, 2006), p. 128; and Kinga Gál, "National Minorities in Inter-State Relations: Commentary from Country Perspectives," in Palermo and Sabanadze, National Minorities in Inter-State Relations, p. 212.

13 As proponents of RtoP are at pains to stress, pillars 1 and 2 of the principle are not about armed intervention. See, for example, Alex J. Bellamy, "The Responsibility to Protect and the Problem of Military Intervention," International Affairs 84, no. 4 (July 2008) pp. 615-39.

${ }^{14}$ The impediment posed by the Security Council and its decision-making rules on confronting harmdoing has been well documented. The political body is cited as a paradigmatic example of multilateral inaction in the face of unfolding humanitarian catastrophes and has been implicated in the death of millions of people due to "egregious non-reactions." For a discussion of these failures in the context of RtoP and kin state activism, see Thakur, "Responsibility to Protect," pp. 11-20; and Ho-Ming So Denduangrudee, "Problems and Prospects for R2P: The Unilateral Action of Viet Nam in 1978," in Kemp et al., Blood and Borders, pp. 146-47.

${ }^{15}$ I draw here on Linklater's inventory of harm, applying it to the experiences of ethnic and linguistic groups and therefore the circumstances relevant to kin state activism. See Andrew Linklater, The Problem of Harm in World Politics: Theoretical Investigations (Cambridge, U.K.: Cambridge University Press, 2011).

${ }^{16}$ Ibid., p. 61; and George Vasilev, Solidarity across Divides: Promoting the Moral Point of View (Edinburgh: Edinburgh University Press, 2015), pp. 20-40.

17 Linklater, Problem of Harm in World Politics, p. 13.

${ }^{18}$ Ibid., p. 61.

19 Jasmin Mujanovic, “Croatian Ruling Party's Dangerous Meddling in Bosnia,” Balkan Insight, October 24, 2018, balkaninsight.com/2018/10/24/croatian-ruling-party-s-dangerous-meddling-in-bosnia-1023-2018/; and Maja Zivanovic, "Serbia Assists Dodik's Election Campaign in Bosnia," Balkan Insight, September 11, 2018, balkaninsight.com/2018/09/11/serbia-assists-dodik-s-election-campaignin-bosnia-09-10-2018/.

${ }^{20}$ Darko Janjevic, “Greater Albania-Bogeyman or a Pipe Dream?,” Deutsche Welle, May 4, 2017, www.dw. com/en/greater-albania-bogeyman-or-a-pipe-dream/a-38705227; and "Tirana Hails United Albanian Stance in Macedonia," Tirana Times, January 13, 2017, www.tiranatimes.com/? $\mathrm{p}=130658$.

${ }^{21}$ Erin Jenne, "A Bargaining Theory of Minority Demands: Explaining the Dog that Did Not Bite in $1990 \mathrm{~s}$ Yugoslavia," International Studies Quarterly 48, no. 4 (December 2004), p. 742.

${ }^{22}$ Elvin Gjevori, "Kin State Non-Interventionism: Albania and Regional Stability in the Western Balkans," Nations and Nationalism 24, no. 1 (July 2017), pp. 171-93.

${ }^{23}$ Olena Shapovalova, "The Role of Russia as a Kin-State in Protecting the Russian Minority in Ukraine," in Kemp et al., Blood and Borders, p. 177.

${ }^{24}$ Stepan Kravchenko, "Putin Promises 'Decisive' Protection for Ethnic Russians Abroad," Bloomberg, October 31, 2018, www.bloomberg.com/news/articles/2018-10-31/putin-promises-decisive-protectionfor-ethnic-russians-abroad.

25 Shapovalova, "Role of Russia as a Kin-State in Protecting the Russian Minority in Ukraine," pp. 174-75, 179 .

${ }^{26}$ John Nagle, "Does Having a Kin State Lessen the Likelihood of Minorities Engaging in Secessionist Mobilization? An Analysis of the Moderating Influence of Kin States," Nationalism and Ethnic Politics 19, no. 3 (2013), pp. 288-89, 300.

27 Andrea Carlà, "South Tyrolean Solutions to Ethnic Conflicts from a Security Studies Perspective," Ethnopolitics Papers 6, no. 42 (2016), p. 10.

${ }^{28}$ Kymlicka, Multicultural Odysseys, pp. 118-121.

29 Thomas Risse and Stephen C. Ropp, "Introduction and Stock-Taking," introduction and overview to Thomas Risse, Stephen C. Ropp, and Kathryn Sikkink, eds., The Persistent Power of Human Rights: From Commitment to Compliance (Cambridge, U.K.: Cambridge University Press, 2013), pp. 3-25.

${ }^{30}$ Alastair Iain Johnston, Social States: China in International Institutions, 1980-200o (Princeton, N.J.: Princeton University Press, 2008).

${ }^{31}$ Gjevori, "Kin State Non-Interventionism," pp. 180-81.

${ }^{32}$ Maria Koinova, "Kinstate Intervention in Ethnic Conflicts: Albania and Turkey Compared," Ethnopolitics 7, no. 4 (2008), pp. 380, 381; Gjevori, "Kin State Non-Interventionism," p. 178.

33 Mersiha Gadzo, "Is Croatia Undermining Bosnia's Sovereignty?," Al Jazeera, December 20, 2018, www. aljazeera.com/indepth/features/croatia-undermining-bosnias-sovereignty-181218142705856.html.

34 John S. Dryzek, Deliberative Democracy and Beyond: Liberals, Critics, Contestations (New York: Oxford University Press, 2000), p. 131. 
35 Human Rights Watch, Denying Ethnic Identity: The Macedonians of Greece (New York: Human Rights Watch, 1994); Gay McDougall, Report of the Independent Expert on Minority Issues: Mission to Greece (Geneva: United Nations Human Rights Council, 2009); Turkish Union of Xanthi and Others v. Greece (app. nos. 55557/12, 73646/13, 7050/14), Eur. Ct. H.R. (2014); Home of Macedonian Civilisation and Others v. Greece (app. no. 1295/10), Eur. Ct. H.R. (2015); Greek Helsinki Monitor, Minority Rights Group-Greece, Humanist Union of Greece, and Coordinated Organizations and Committees for Roma Human Rights in Greece, "Greece: Non-Recognition of Macedonian \& Turkish Minorities Despite ECtHR Rulings," statement presented at the 2015 OSCE Human Dimension Implementation Meeting, Warsaw, Poland, October 1, 2015; and "European Parliament Conference on Minority Rights in Greece Violently Interrupted by Greek Members of Parliament," FUEN, March 7, 2016, www.fuen.org/news/single/article/european-parliament-conference-on-minority-rights-in-greeceviolently-interrupted-by-greek-members-of-parliament/.

${ }^{36}$ Thakur, "Responsibility to Protect," p. 59.

37 Ibid., p. 21.

${ }^{38}$ Vasilev, Solidarity across Divides, pp. 30-40.

Abstract: A notable feature of nationalism's contemporary resurgence is the increasing eagerness of governments to support and shape the political causes of populations living abroad that are viewed as ethnic kindred. However, global criteria for judging when such kin state activism is and is not acceptable have so far remained elusive, as the objectionable instances of the practice tend to overshadow the legally and morally consistent ones. I argue that the analysis of world affairs and promotion of global justice would benefit from an ethic of transnational conduct that has a rightful place for kin states. I defend a set of cosmopolitan criteria for this purpose, outlining how they enable us to recognize and combat the dangers posed by certain forms of kin state mobilization without forgoing the opportunities presented by certain other forms to overcome minority repression and enhance regional security.

Keywords: cosmopolitanism, ethnic conflict, human rights, kin states, minority rights, nationalism, transnational activism 